\title{
UJI DAYA HAMBAT BERBAGAI JENIS BAKTERI TERHADAP PERKEMBANGAN Vibrio harveyi PADA PEMELIHARAAN LARVA KEPITING BAKAU (Scylla serrata)
}

\author{
Imam Taufik*) dan Zafran*)
}

\begin{abstract}
ABSTRAK
Rendahnya sintasan larva kepiting bakau (Scylla serrata) antara lain disebabkan karena infeksi bakteri Vibrio harveyi. Upaya penanggulangan yang efektif dan aman dapat dilakukan secara biologis dengan memanfaatkan bakteri lain yang bersifat sebagai kompetitor bagi $V$. harveyi.

Melalui uji daya hambat pada media Marine Agar (MA) ditemukan 23 isolat bakteri yang mempunyai kemampuan dalam menghambat perkembangan $V$. harveyi dan di antaranya terdapat 3 isolat bakteri (GRS-95097, GRS-95154 dan GRS-95155) dengan daya hambat yang baik. Hasil uji di laboratorium terhadap larva kepiting bakau yang diinfeksi $V$. harveyi pada kepadatan $6,9 \times 10^{4} \mathrm{cfu}$ (colony forming unit) $/ \mathrm{mL}$ menunjukkan bahwa penambahan bakteri kompetitor ke dalam air pemeliharaan larva dalam waktu 24 jam dapat meningkatkan sintasan larva. Isolat GRS-95154 dengan kepadatan $2,4 \times 10^{7} \mathrm{cfu} / \mathrm{mL}$ menghasilkan sintasan $82 \%$, isolat GRS-95097 dengan kepadatan $2,2 \times 10^{7} \mathrm{cfu} / \mathrm{mL}$ menghasilkan sintasan 77,67\%, isolat GRS-95155 dengan kepadatan $5,5 \times 10^{7} \mathrm{cfu} / \mathrm{mL}$ menghasilkan sintasan $75 \%$ dan berbeda nyata $(\mathrm{P}<0,05)$ dengan kontrol (tanpa bakteri kompetitor) dengan sintasan 61,67\%.

Dapat disimpulkan bahwa ketiga isolat mampu menekan perkembangan $V$. harveyi dan menurunkan patogenisitasnya terhadap larva kepiting bakau. Klasifikasi menunjukkan bahwa ketiga isolat termasuk ke dalam genus Vibrio.

ABSTRACT: Inhibition test of various bacteria on the growth of luminescent Vibrio harveyi during the rearing period of mangrove crab larvae (Scylla serrata). By: Imam Taufik and Zafran.

The larvae of mangrove crab (Scylla serrata) was found to be sensitive to infection by luminescent Vibrio harveyi. Biocontrol of this disease by a bacterium is expected to solve this problem. Twenty three of 167 isolates of bacteria were found to be effective to inhibit the growth of V. harveyi on Marine Agar but only three isolates gave best results, i.e. GRS-95097, GRS-95154, and GRS-95155. From the rearing experiment of the larvae infected with $V$. harveyi at concentration of $6.9 \times 10^{4}$ colony forming unit $/ \mathrm{mL}$, addition of isolate GRS-95097 at concentration of $2.2 \times 10^{7} \mathrm{cfu} / \mathrm{mL}$, isolate GRS-95154 at concentration of $2.4 \times 10^{7} \mathrm{cfu} / \mathrm{mL}$, and isolate GRS95155 at concentration of $5.5 \times 10^{7} \mathrm{cfu} / \mathrm{mL}$ gave higher survival rates $(P<0.05)$ of mud crab larvae than control (without infection), i.e. $77.67 \%, 82.00 \%, 75.00 \%$, and $61.67 \%$ respectively. As a conclusion, all three isolates were effective to control luminescent $V$. harveyi infection during the rearing period of mangrove crab larvae. Identification of the isolated bacteria showed that the three isolates belong to genus Vibrio.
\end{abstract}

KEYWORDS: Biocontrol, Scylla serrata, Vibrio harveyi.

\section{PENDAHULUAN}

Kegiatan penangkapan kepiting bakau (Scylla serrata) di alam semakin tinggi intensitasnya untuk memenuhi permintaan pasar akan komoditas tersebut yang kenyataannya dari tahun ke tahun mengalami peningkatan cukup besar (Ditjen Perikanan, 1993). Penangkapan cenderung dilakukan terhadap kepiting bertelur karena harganya lebih mahal dibandingkan kepiting jantan atau yang tidak bertelur. Kegiatan tersebut bila dilakukan secara terus menerus dan

* Peneliti pada Loka Penelitian Perikanan Pantai Gondol, Bali 
tidak terkendali dapat mengancam kelestarian populasi kepiting bakau di alam.

Sejak tahun 1992, Loka Penelitian Perikanan Pantai Gondol telah melakukan rintisan perbenihan kepiting bakau sebagai solusi bagi pasok kebutuhan benih untuk budidaya serta usaha pelestarian di alam, tetapi sejauh ini tingkat sintasan larva yang dihasilkan masih sangat rendah, yaitu di bawah 1\% (Rusdi et al., 1993). Mortalitas paling tinggi terjadi pada stadia zoea yang antara lain disebabkan oleh adanya infeksi jamur dari jenis Lagenidium spp. dan Haliphthoros spp. (Bian et al., 1979; Sindermann, 1988). Dilaporkan pula bahwa vibrio bercahaya (Vibrio harveyi) cukup patogen dan dapat menyebabkan kematian massal bagi larva kepiting bakau, bahkan kemungkinan terinfeksinya cukup besar karena selama masa pengeraman telur berada di luar tubuh induk (Boer et al., 1993).

Penggunaan antibiotik untuk menanggulangi infeksi bakteri bercahaya telah dicoba (Zafran dan Roza, 1993), tapi dampak penggunaan yang kurang teruji secara laboratoris dapat meningkatkan resistensi bakteri dan mempengaruhi/menurunkan vitalitas larva terutama pada stadia awal yang mengalami proses ganti kulit. Penanggulangan akan lebih aman bila dilakukan secara biologis, misalnya dengan memanfaatkan mikroorganisme. Sehubungan dengan hal tersebut penelitian ditujukan untuk mencari mikroorganisme (bakteri) yang mampu menghambat perkembangan vibrio bercahaya tetapi tidak bersifat patogen bagi larva kepiting bakau.

\section{BAHAN DAN METODE}

\section{Isolasi Bakteri}

Bakteri dari berbagai perairan pantai di daerah Bali, Jawa Timur dan Lombok diisolasi dengan cara menuangkan $0,1 \mathrm{~mL}$ air laut/payau tersebut secara merata pada media padat TSA (Triptic Soy Agar) kemudian diinkubasi pada suhu $27^{\circ} \mathrm{C}$ selama 24 jam. Bakteri yang tumbuh pada media tersebut dengan penampakan bentuk dan warna koloni yang berbeda masing-masing diisolasi dan dimurnikan pada media MA (Marine Agar) dan diinkubasikan pada suhu $27^{\circ} \mathrm{C}$ hingga diperoleh isolat murni dari setiap koloni bakteri.

Vibrio bercahaya yang digunakan untuk infeksi buatan diisolasi dari larva kepiting bakau yang terinfeksi dan sebelum digunakan bakteri tersebut diaktifkan kembali dengan cara menginfeksikan ulang terhadap larva kepiting bakau.

\section{Uji Daya Hambat pada Media Padat}

Dengan menggunakan media MA, setiap isolat bakteri yang diperoleh diuji kemampuannya dalam menghambat vibrio bercahaya dengan metode yang digunakan oleh Maeda (1994) sebagai berikut.

Pada media MA dibuat dua goresan bakteri sepanjang $4 \mathrm{~cm}$ dengan jarak antara goresan $3 \mathrm{~cm}$ (masing-masing dibuat 2 buah), selanjutnya diinkubasikan pada suhu $27^{\circ} \mathrm{C}$ selama 3 dan 6 hari. Setelah masa inkubasi, di antara kedua bakteri digoreskan isolat vibrio bercahaya sepanjang 2 $\mathrm{cm}$ dan diinkubasikan kembali pada suhu $27^{\circ} \mathrm{C}$ selama 24-72 jam untuk kemudian diamati pertumbuhannya. Bila goresan vibrio tampak menebal dan melebar berarti vibrio bercahaya dapat tumbuh secara normal tanpa hambatan, tetapi bila goresan tetap tipis menandakan bahwa pertumbuhan vibrio bercahaya terhambat oleh bakteri uji. Sebagai pembanding bagi pertumbuhan bakteri disediakan goresan tunggal vibrio bercahaya pada cawan petri tanpa bakteri uji.

Dari hasil uji daya hambat, diseleksi isolat bakteri yang menunjukkan kemampuan paling besar dalam menghambat vibrio bercahaya untuk kemudian digunakan sebagai perlakuan pada uji selanjutnya.

\section{Uji Patogenisitas}

Isolat bakteri terseleksi (penghambat) yang akan dijadikan perlakuan terlebih dahulu diuji patogenisitasnya terhadap larva kepiting bakau (zoea-1), yaitu dengan cara menginfeksikan suspensi masing-masing bakteri pada tingkat kepadatan infeksi $10^{6}, 10^{7}$ dan $10^{8} \mathrm{cfu} / \mathrm{mL}$ ke dalam media/air pemeliharaan larva kepiting bakau yang ditebar dengan kepadatan 50 individu/liter. Bila sampai pada tingkat kepadatan $10^{7} \mathrm{cfu} / \mathrm{mL}$ tidak mematikan larva, isolat tersebut dianggap tidak patogen dan aman bagi larva kepiting bakau. Dalam uji patogenisitas, larva yang dipelihara tidak diberi pakan sehingga waktu pengamatan disesuaikan dengan ketahanan hidup larva tanpa makanan, yaitu selama 48 jam. 
Vibrio bercahaya terbukti cukup patogen bagi larva kepiting bakau, dari hasil penelitian menunjukkan bahwa pada tingkat kepadatan $10^{3}$ $\mathrm{cfu} / \mathrm{mL}$ sudah dapat menyebabkan kematian larva $>50 \%$ dalam waktu 24 jam (Boer et al., 1993).

\section{Uji Daya Hambat pada Pemeliharaan Larva}

Wadah yang digunakan berupa stoples kaca yang diisi $1 \mathrm{~L}$ air laut bebas bakteri (telah disterilkan dulu pada suhu $121^{\circ} \mathrm{C}$ selama 15 menit). Larva kepiting bakau (zoea-1) sebagai hewan uji diperoleh dari panti benih kepiting Lolitkanta Gondol dan ditebar dengan kepadatan $100 \mathrm{individu/L}$.

Ke dalam setiap wadah penelitian diinfeksikan vibrio bercahaya hingga kepadatannya mencapai $10^{4} \mathrm{cfu} / \mathrm{mL}$ dalam air pemeliharaan larva. Perlakuan berupa penambahan suspensi bakteri penghambat pada air pemeliharaan larva pada kepadatan $10^{7} \mathrm{cfu} / \mathrm{mL}$. Perhitungan sintasan larva dilakukan setelah 24 jam perlakuan.

\section{Klasifikasi Bakteri}

Terhadap isolat bakteri penghambat yang mampu memberikan sintasan terbaik bagi larva kepiting bakau dilakukan beberapa uji biologis dan bio-kimia untuk mengetahui karakternya, demikian pula terhadap vibrio bercahaya yang digunakan sebagai infeksi buatan. Klasifikasi bakteri berpedoman kepada Baumann et al. (1984).

\section{HASIL DAN PEMBAHASAN}

\section{Isolasi dan Uji Daya Hambat}

Dari hasil isolasi serta purifikasi bakteri beberapa contoh air diperoleh 167 isolat bakteri dengan bentuk dan warna koloni yang berbeda. Melalui uji daya hambat pada media padat (MA) ternyata terdapat 23 isolat yang mampu meng. hambat pertumbuhan vibrio bercahaya untuk masa inkubasi tiga hari atau enam hari, di mana vibrio yang digoreskan di antara isolat penghambat tidak berkembang dan secara nyata dapat dibedakan dengan kontrol yang memberikan pertumbuhan yang menebal dan melebar.
Di antara 23 isolat bakteri terdapat tiga isolat dengan daya hambat yang terbaik dibanding isolat lain. Vibrio bercahaya yang diinokulasikan di antara masing-masing isolat tersebut sama sekali tidak dapat berkembang, tampak dari goresan yang sama sekali tidak berubah (menebal atau melebar) dari ukuran semula, baik untuk masa inkubasi tiga hari maupun enam hari. Isolat tersebut adalah GRS-95097; GRS-95154 dan GRS-95155 (Tabel 1) hasil isolasi dari perairan pantai dan tambak di daerah Jawa Timur dengan penampilan koloni warna kuning pada media Thiosulphate Citrate Bile Salt Sucrose Agar (TCBSA).

\section{Uji Patogenisitas}

Uji patogenisitas dimaksudkan untuk mengetahui tingkat keamanan isolat bakteri terhadap larva kepiting bakau sebelum digunakan untuk uji dalam pemeliharaan larva. Hasil selengkapnya dapat dilihat pada Tabel 2 .

Dari Tabel 2 terlihat bahwa infeksi isolat penghambat dalam air pemeliharaan larva sampai tingkat kepadatan $10^{8} \mathrm{cfu} / \mathrm{mL}$ dalam waktu 24 jam bahkan 48 jam tidak patogen terhadap larva kepiting bakau di mana sintasan larva kepiting bakau yang diinfeksi tidak berbeda dengan kontrol $(\mathrm{P}>0,05)$. Kematian beberapa larva yang dialami bukan akibat infeksi isolat bakteri penghambat sebab kondisi serupa juga terjadi pada kontrol yang tidak diinfeksi. Jadi kematian disebabkan oleh vitalitas larva yang kurang baik. Dengan demikian isolat GRS-95097; GRS-95154; dan GRS-95155 dapat diuji daya hambatnya terhadap vibrio bercahaya dalam pemeliharaan larva kepiting bakau.

\section{Uji Daya Hambat dalam Pemeliharaan Larva}

Setelah 24 jam, dengan kepadatan infeksi vibrio bercahaya dalam air pemeliharaan sebanyak $6,9 \times 10^{4} \mathrm{cfu} / \mathrm{mL}$ ternyata sintasan larva pada tiap perlakuan dan kontrol mencapai lebih dari $50 \%$. Rata-rata sintasan paling tinggi (82\%) diperoleh pada perlakuan penambahan suspensi isolat GRS-95154 dengan kepadatan $2,4 \times 10^{7}$ $\mathrm{cfu} / \mathrm{mL}$, isolat GRS-95097 (2,2x10 $\mathrm{cfu} / \mathrm{mL})$ dengan sintasan 77,67\%, dan isolat GRS-95155 (5,5 x 10 $\mathrm{cfu} / \mathrm{mL}$ ) sebanyak $75 \%$. Sintasan paling rendah dialami pada kontrol, yaitu $61,67 \%$ (Tabel 3). 
Tabel 1. Kemampuan isolat bakteri dalam menghambat pertumbuhan vibrio bercahaya pada media MA.

Table 1. Capability of isolates to inhibit the growth of luminescent vibrio on MA.

\begin{tabular}{|c|c|c|}
\hline \multirow{2}{*}{$\begin{array}{l}\text { Isolat } \\
\text { Isolate }\end{array}$} & \multicolumn{2}{|c|}{ Daya hambat (Inhibition rate) } \\
\hline & $\begin{array}{l}3 \text { hari inkubasi } \\
3 \text { days incubation }\end{array}$ & $\begin{array}{l}6 \text { hari inkubasi } \\
6 \text { days incubation }\end{array}$ \\
\hline GRS-95005 & - & + \\
\hline GRS-95045 & - & ++ \\
\hline GRS-95046 & - & + \\
\hline GRS-95048 & - & + \\
\hline GRS-95050 & - & + \\
\hline GRS-95052 & - & + \\
\hline GRS-96085 & + & + \\
\hline GRS-95095 & - & + \\
\hline GRS-95097 & ++ & +++ \\
\hline GRS-95098 & + & + \\
\hline GRS-95107 & ++ & + \\
\hline GRS-95125 & - & + \\
\hline GRS-95126 & - & ++ \\
\hline GRS-95129 & + & + \\
\hline GRS-95140 & - & + \\
\hline GRS-95144 & - & + \\
\hline GRS-95145 & ++ & . \\
\hline GRS-95148 & - & + \\
\hline GRS-95149 & - & + \\
\hline GRS-95150 & + & ++ \\
\hline GRS-95154 & +++ & ++ \\
\hline GRS-95155 & ++ & ++ \\
\hline GRS-95159 & + & + \\
\hline
\end{tabular}

$=$ tidak ada daya hambat terhadap perkembangan bakteri $V$. harveyi (no inhibition for bacteria for V. Harveyi)

$=$ terdapat sedikit hambatan terhadap perkembangannya bakteri V. harveyi (there is inhibition for bacteria of $V$. Harveyi)

${ }_{+}^{+}=$terdapat hambatan dengan tingkatan medium terhadap perkembangan bakteri $V$. harveyi (there is moderate inhibition for bacteria of $V$. harveyi)

${ }_{++}^{+}=$terdapat hambatan yang kuat terhadap perkembangan bakteri $V$. harveyi (there is strong inhibition for bacteria of V. harveyi) 
Tabel 2. Uji patogenisitas isolat bakteri terhadap larva (zoea-1) kepiting bakau.

Table 2. Pathogenicity test of bacteria isolates to larvae (zoea-1) of mangrove crabs.

\begin{tabular}{c|c|c|c}
\hline \multirow{2}{*}{$\begin{array}{c}\text { Isolat } \\
\text { Isolates }\end{array}$} & $\begin{array}{c}\text { Kepadatan } \\
\text { bakteri } \\
\text { Bacteria density } \\
\text { (cfu/mL) }\end{array}$ & $\begin{array}{c}\text { Sintasan } \\
\text { (Survival Rate) } \\
\text { (\%) }\end{array}$ \\
\cline { 3 - 4 } GRS-95097 & $5.6 \times 10^{8}$ & 81 & $\begin{array}{c}\text { 48 jam } \\
\mathbf{2 4} \text { hours }\end{array}$ \\
& $5.6 \times 10^{7}$ & 86 & 71 \\
& $5.6 \times 10^{6}$ & 92 & 74 \\
GRS-95154 & $2.0 \times 10^{8}$ & 92 & 72 \\
& $2.0 \times 10^{7}$ & 88 & 65 \\
& $2.0 \times 10^{6}$ & 91 & 65 \\
GRS-95155 & $2.2 \times 10^{8}$ & 86 & 69 \\
& $2.2 \times 10^{7}$ & 92 & 65 \\
& $2.2 \times 10^{6}$ & 94 & 68 \\
& Tanpa infeksi & 100 & 75 \\
\hline \multirow{2}{*}{ Kontrol } & Without infection & & 73 \\
\hline
\end{tabular}

Tabel 3. Sintasan larva kepiting bakau yang diinfeksi dengan isolat bakteri selama 24 jam. Table 3. Survival rate of mangrove crabs larvae infected with isolated bacteria for 24 hours.

\begin{tabular}{c|c|c|c|c|c}
\hline \multirow{2}{*}{$\begin{array}{c}\text { Isolat yang } \\
\text { diinfeksikan } \\
\text { Isolates infected }\end{array}$} & \multicolumn{3}{|c|}{ Ulangan (Replication) } & \multirow{2}{*}{ Total } & $\begin{array}{c}\text { Rata-rata* } \\
\text { Average* }\end{array}$ \\
\cline { 2 - 4 } & $\mathbf{1}$ & $\mathbf{2}$ & $\mathbf{3}$ & & $61.67^{\mathrm{a}}$ \\
Kontrol (Control) & 59 & 66 & 60 & 185 & $75.00^{\mathrm{b}}$ \\
GRS-95155 & 76 & 78 & 71 & 225 & $77.67^{\mathrm{b}}$ \\
GRS-09597 & 72 & 82 & 79 & 233 & $82.00^{\mathrm{b}}$ \\
GRS-95154 & 84 & 81 & 81 & 246 & \\
\hline
\end{tabular}

*) angka dalam kolom yang diikuti huruf superskrip yang sama menunjukkan tidak berbeda nyata $(\mathrm{P}>0,05)$

*) value in column with the same superscript indicated not significantly different $(P>0.05)$

Hasil sidik ragam terhadap sintasan larva kepiting bakau yang diinfeksi bakteri bercahaya ternyata berbeda nyata $(\mathrm{P}<0,05)$ antara ketiga perlakuan dengan kontrol, sedangkan antara perlakuan satu dengan lainnya tidak berbeda nyata $(\mathrm{P}>0,05)$. Hal ini dapat diasumsikan bahwa penambahan suspensi isolat GRS-95097; GRS. 95154 maupun GRS-95155 ke dalam air pemeliharaan akan berpengaruh terhadap sintasan larva kepiting bakau yang terinfeksi vibrio bercahaya.
Jumlah/kepadatan vibrio bercahaya akan sangat mempengaruhi patogenisitasnya terhadap larva. Semakin tinggi kepadatannya akan semakin patogen, demikian pula sebaliknya. Ternyata dengan menambahkan suspensi masingmasing isolat ke dalam air pemeliharaan larva dapat menurunkan mortalitas larva akibat infeksi vibrio bercahaya, karena isolat tersebut mampu menekan populasi vibrio bercahaya dan menurunkan patogenisitasnya terhadap larva. 
Faktor internal penyebab menurunnya patogenisitas vibrio bercahaya terhadap larva kepiting bakau diduga karena isolat GRS-95097; GRS95154 dan GRS-95155 mampu menghasilkan antibiotik yang menjadi penghambat bagi perkembangan vibrio bercahaya. Antibiotik merupakan bahan kimia yang dihasilkan oleh organisme hidup yang dapat menghambat atau membunuh mikroba. Organisme yang dimaksud adalah mikroba seperti bakteri, actinomycetes dan fungi (Dewipadma, 1987). Di perairan bebas terdapat beberapa jenis bakteri yang mampu memproduksi antibiotik (Anderson \& Nelson, 1974).

Kemungkinan lain adalah terjadinya korelasi negatif antara vibrio bercahaya dengan isolat bakteri penghambat (GRS-95097; GRS-95154 dan GRS-95155) sehingga tercipta suasana kompetitif dalam media yang terbatas. Karena kepadatan bakteri penghambat lebih tinggi $\left( \pm 10^{7} \mathrm{cfu} / \mathrm{mL}\right)$ dibanding bakteri bercahaya $\left(10^{4} \mathrm{cfu} / \mathrm{mL}\right)$, maka dalam kondisi demikian akan menyebabkan vibrio bercahaya tidak dapat berkembang karena terhambat oleh bakteri kompetitor.

\section{Identifikasi Bakteri}

Dari hasil uji yang dilakukan terhadap isolat bakteri penghambat dengan berpedoman kepada Baumann et al. (1984) ternyata ketiga isolat tersebut tergolong ke dalam genus Vibrio dengan karakter antara lain memberikan reaksi negatif untuk arginin, positif untuk ornithin dan lysin serta tumbuh pada media TCBSA (Tabel 4). Sedangkan vibrio bercahaya yang digunakan untuk infeksi buatan pada larva kepiting bakau termasuk ke dalam jenis Vibrio harveyi dengan karakteristik seperti terlihat pada Tabel 5, dengan karakter yang paling mudah dibedakan dengan jenis bakteri lain, yaitu koloninya mampu menghasilkan cahaya dalam kondisi gelap.

Hasil penelitian Garriques \& Arevalo (1995) membuktikan bahwa penambahan bakteri Vibrio alginolyticus yang koloninya berwarna kuning pada media TCBSA ke dalam air pemeliharaan larva ternyata dapat meningkatkan pertumbuhan dan sintasan Penaeus vannamei secara probiotik.

Tabel 4. Karakteristik isolat bakteri dibandingkan dengan Vibrio menurut Baumann et al. (1984).

Table 4. Characteristics of isolated bacteria in comparison with Vibrio according to Baumann et al. (1984).

\begin{tabular}{|c|c|c|c|c|}
\hline \multirow{2}{*}{$\begin{array}{c}\text { Karakteristik } \\
\text { Characteristics }\end{array}$} & \multicolumn{3}{|c|}{ Isolat (Isolate) } & \multirow{2}{*}{$\begin{array}{c}\text { Vibrio } \\
\text { (Baumann et al., } \\
1984) \\
\end{array}$} \\
\hline & GRS-95097 & GRS-95154 & GRS-95155 & \\
\hline Gram stain & - & - & - & - \\
\hline Motility & + & + & + & + \\
\hline Oxidase & + & + & + & + \\
\hline Catalase & + & + & + & + \\
\hline \multicolumn{5}{|l|}{ Sensitive to: } \\
\hline $0 / 129$ & $\mathrm{~S}$ & $\mathrm{~S}$ & $\mathrm{~S}$ & S \\
\hline Novohiocin & $\mathrm{S}$ & $S$ & $\mathrm{~S}$ & $\mathrm{~S}$ \\
\hline Arginine & - & - & . & - \\
\hline Ornithin decarboxylase & + & + & + & + \\
\hline Lysin & + & + & + & + \\
\hline \multicolumn{5}{|l|}{ Growth in $\mathrm{NaCl}$ : } \\
\hline $0.0 \%$ & - & - & - & - \\
\hline $0.5 \%$ & + & + & + & + \\
\hline $3.0 \%$ & + & + & + & + \\
\hline $6.0 \%$ & + & + & + & + \\
\hline $8.0 \%$ & + & + & + & + \\
\hline $10.0 \%$ & - & - & - & - \\
\hline Growth on TCBSA & $\mathrm{Y}$ & $\mathrm{Y}$ & $\mathrm{Y}$ & $\mathrm{Y}$ \\
\hline
\end{tabular}

- = negatif (negative) $+=$ positif (positive)

$\mathrm{S}=$ peka (sensitive); $\mathrm{Y}=\mathrm{kuning}$ (yellow) 
Tabel 5. Karakteristik vibrio bercahaya dibandingkan dengan Vibrio harveyi menurut Baumann et al. (1984).

Table 5. Characteristics of luminescent vibrio in comparison with Vibrio harveyi according to Baumann et al. (1984).

\begin{tabular}{|c|c|c|}
\hline $\begin{array}{c}\text { Karakteristik } \\
\text { Characteristics } \\
\end{array}$ & $\begin{array}{l}\text { Isolat vibrio } \\
\text { Isolate vibrio } \\
\end{array}$ & $\begin{array}{c}\text { Vibrio harveyi } \\
\text { (Baumann et al., 1984) }\end{array}$ \\
\hline $\begin{array}{l}\text { Shape } \\
\text { Gram stain } \\
\text { S I M } \\
\mathrm{H}_{2} \mathrm{~S} \\
\text { Indole } \\
\text { Motility } \\
\text { Oxidase } \\
\text { Catalase } \\
\text { O - F } \\
\text { Kligler test } \\
\text { Gas from glucose } \\
\text { Sensitive to: } \\
\text { 0/129 } \\
\text { Novobiocin } \\
\text { O'TC } \\
\text { Chloramphenicol } \\
\text { Erithromycin } \\
\text { Growth on TCBS agar } \\
\text { Growth in NaCl : } \\
\text { 0\% } \\
\text { 1\% } \\
\text { 3\% } \\
\text { 6\% } \\
\text { 8\% } \\
\text { Utilization of : } \\
\text { Glucose } \\
\text { Cellobiose } \\
\text { Maltose } \\
\text { Melibiose } \\
\text { Lactose } \\
\text { Sucrose } \\
\text { Sorbitol } \\
\text { Mannose } \\
\text { L-Ornithine } \\
\text { L-Arginine }\end{array}$ & $\begin{array}{l}\text { R } \\
- \\
\cdot \\
+ \\
+ \\
+ \\
+ \\
\text { F } \\
\text { R/Y } \\
\cdot \\
\text { S } \\
\text { S } \\
\text { S } \\
\text { S } \\
\mathrm{R} \\
\text { G } \\
- \\
+ \\
+ \\
+ \\
+ \\
+ \\
+ \\
+ \\
+ \\
- \\
+ \\
- \\
+ \\
+ \\
+ \\
-\end{array}$ & $\begin{array}{l}\text { R } \\
- \\
- \\
+ \\
+ \\
+ \\
+ \\
\text { F } \\
\mathrm{R} / \mathrm{Y} \\
- \\
\\
\mathrm{S} \\
\mathrm{S} \\
\mathrm{S} \\
\mathrm{S} \\
\mathrm{R} \\
\mathrm{G} \\
- \\
+ \\
+ \\
+ \\
+ \\
+ \\
+ \\
+ \\
+ \\
- \\
+ \\
- \\
+ \\
+ \\
+\end{array}$ \\
\hline $\begin{aligned} \mathrm{R} & =\text { tahan (resistan } \\
\mathrm{F} & =\text { fermentatif (fer } \\
\mathrm{R} / \mathrm{Y} & =\text { merah/kuning } \\
\mathrm{S} & =\text { peka (sensitive) } \\
\mathrm{G} & =\operatorname{hijau}(\text { green) }\end{aligned}$ & & \\
\hline
\end{tabular}




\section{KESIMPULAN DAN SARAN}

\section{Kesimpulan}

Isolat bakteri GRS-95097, GRS-95154 dan GRS-95155 mampu menghambat perkembangan vibrio bercahaya (Vibrio harveyi), baik pada media padat maupun dalam pemeliharaan larva sehingga menurunkan mortalitas larva kepiting bakau akibat infeksi vibrio bercahaya.

Ketiga isolat bakteri termasuk genus Vibrio dan tidak patogen bagi larva sehingga dapat digunakan untuk mengendalikan infeksi $V$. harveyi pada pemeliharaan larva kepiting bakau.

\section{Saran}

Perlu dilakukan penelitian lebih lanjut mengenai mekanisme isolat GRS-95097, GRS95154 dan GRS-95155 dalam menghambat perkembangan Vibrio harveyi.

\section{DAFTAR PUSTAKA}

Anderson, D.P. and Nelson, J.R. 1974. Comparison of protection in rainbow trout (Salmogairdneri) inoculated with and fed Hagerman redmouth bacterias. Journal of the Fisheries Research Board of Canada (31):214-216.

Baumann, P., A.L. Furnis, and J.V. Lee. 1984. Facultatively anaerobic gramnegative rods. In N.R. Krieg (ed.), Bergey's manual of systematic bacteriology, Volume 1, Williams and Wilkins, Baltimore, USA: 518-538.

Bian, B.Z., K. Hatai, G. Lio-Po and S. Egusa. 1979. Studies of the fungal diseases in crustacea I
Lagenidium scylla sp. isolated from cultivated ova and larvae of the mangrove crab, Scylla serrata. Trans. Mycol. Soc. Japan, 20: 115 - 124.

Boer, D.R., Zafran, A. Parenrengi dan A. Taufik. 1993. Studi pendahuluan penyakit kunang-kunang pada larva kepiting bakau, Scylla serrata. J. Penel. Budidaya Pantai, 9(3): 119 - 124.

Dewipadma, J.K. 1987. Pertumbuhan bakteri. Dalam B.H. Limas, Y.K Dewipadma dan S.L. Angka (ed). Mikrobiologi Umum. Proyek Peningkatan/Pengembangan Perguruan Tinggi. Institut Pertanian Bogor: 30-52.

Direktorat Jendral Perikanan. 1993. Statistik Perikanan Indonesia 1991. Departemen Pertanian, Jakarta. 72 hal.

Garriques, D., and G. Arevalo. 1995. An evaluation of the production and use of a live bacterial isolate to manipulate the microbial flora in the commercial productin of Penaeus vannamei post larvae in Equador. Granjas Marinas El Rosario S.A., Guayaquil, Equador. pp. 53-59.

Maeda, M. 1994. Biocontrol of the larvae rearing biotop in aquaculture. Bulletin National Research Institute of Aquaculture. Nansei, Japan. 1:71-74

Rusdi, I., A. Parenrengi dan D. Makatutu. 1993. Pengaruh perbedaan salinitas terhadap penetasan dan kelangsungan hidup zoea awal kepiting bakau, Scylla serrata. Jurnal Penelitian Budidaya Pantai 9(1): $141-146$.

Sinderman, C.J. 1988. Fungus (Lagenidium) diseases of blue crab eggs and larvae. In C.J. Sinderman and D.V. Lightner (ed.), Disease diagnosis and control in North American Marine Aquaculture: 215-219.

Zafran dan D. Roza. 1993. Teknik penanggulangan penyakit udang menyala di hatchery melalui pengendalian populasi bakteri. Jurnal Penelitian Budidaya Pantai 9(2): 127-132. 